series of reactions requires the hydrolytic split of a phosphate group of fructose-1 : 6-diphosphate.

G. G. SanwaL

P. S. KrishnaN

Division of Biochemistry,

Lucknow University,

Lucknow.

${ }^{1}$ Walker, D. A., Biochem. $J_{.,}$67, 73 (1957).

${ }^{2}$ Walker, D. A., and Brown, J. M. A., Biochem. J., 67, 79 (1957).

${ }^{3}$ Walker, D. A., Biochem. J., 74, $216(1960)$.

- Sibley, J. A., and Lehninger, A. L., J. Biol. Chem., 17\%, 859 (1949).

sanwal, G. G., and Krishnan, P. S., Enzymologia, 22, 51 (1960).

\section{Biochemical Chlorination in Streptomyces aureofaciens}

THrs communication is concerned with the effect of chlorinated fatty acids on the formation of chlortetracycline. Experiments were carried out with shake cultures of Streptomyces aureofaciens, strain $B-28$ (ref. 1).

It has already been shown ${ }^{1-2}$ that some strains of Streptomyces aureofaciens are able to utilize exhaustively the chloride content of an available medium for the synthesis of chlortetracycline. We have found that replacing the inorganic chloride of the medium by the organically bound chlorine of some chloro-fatty acids, the micro-organism was capable of using this different source of chlorine also for the synthesis of chlortetracycline. Quantitative differences could be detected in the rate of utilization of chlorine, depending on the structural position of the chlorine atom (Table 1). This type of chlorination was also substantially inhibited by bromide as well as 2,5-dimercapto-1,3,4-thiadiazole.

Table 1. UTILIzATION OF THE CHLORINE OF CHLORO-FATTY ACIDS FOR THE BIOSYNTHESIS OF CHLORTETRACYCIINE

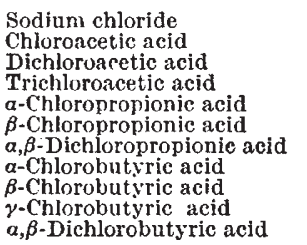

$\left(1 \cdot 5 \times 10^{-3} M\right)$
,$"$
$"$,
$"$,
$"$,
$"$,
$"$,
$"$,

Per cent

Per cent
$100 \cdot 0$
$84 \cdot 5$
$10 \cdot 1$
$4 \cdot 9$
$4 \cdot 7$
$67 \cdot 3$
$21 \cdot 7$
$8 \cdot 3$
$53 \cdot 9$
$70 \cdot 3$
$12 \cdot 3$

Considering the possibilities of chlorine utilization from chloro-fatty acids, three pathways may be suggested as shown in Fig. 1.

The first step in reaction 1 supposes a dechlorination of the chloro-fatty acid (enzymic or spontaneous) yielding inorganic chloride which would be utilized further in the usual way. The second reaction may be regarded as a 'transchlorination' process, that is, a transfer of chlorine from one substrate to another without mixing with inorganic chloride. In the case of the third reaction incorporation proceeds

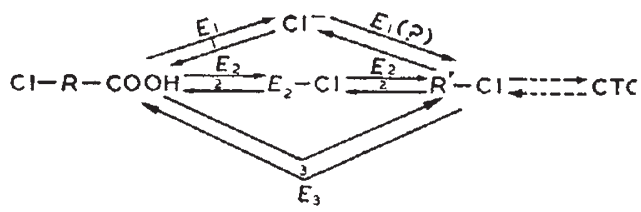

Fig. 1. $E_{1}, E_{2}$ and $E_{3}$ represent the enzymes or enzyme systems catalysing the different reaction patterns. $R$ is substituted for a single or longer hydrocarbon chain, while $R^{\prime}$ has to be interpreted as a common hypothetical intermediate of the biosynthetic process leading to tetracyclines, which can be chlorinated to form chlortetracycline (CTC) otherwise in the absence of utilizable chlorine it participates in tetracycline production without the cleavage of the original carbon-chlorine bond of the chloro-fatty acid.

Since our experimental results (to be published elsewhere) precluded the possibility of spontaneous chlorine decomposition, only an active enzymic dechlorination can be assumed for the first case. On the basis of our early investigations, occurrence of the third reaction type seems to be less probable. This conclusion is supported by the incorporation results obtained with the isomeric chloro-butyric acids, too ; namely, in the case of an incorporation reaction proceeding without the cleavage of the carbon-chlorine linkage-particularly fragmentation of the fatty acid molecule is reasonably assumed by this process-the significant differences yielded with the chloro-butyric acids (Table l) are scarcely interpretable. Considering the intramolecular structural arrangements of the variously substituted acids and the possibility of steric inhibition, results summarized in Table 1 cen be well explained on the basis of reaction 1 or 2 . More detailed results and discussion will be published shortly, elsewhere.

S. J. KoLLARR

M. JARAI

Biochemical and Microbiological Laboratories, Department of Antibiotics,

'Chinoin' Chemical and Pharmaceutical Works, Budapest.

${ }^{1}$ Kollár, S. J., and Járai, M., Acta Microbiol. Hung., 7, 1 (1960).

${ }^{2}[D o e r s c h u k$, A. P., McCormick, J. R. D., Grodman, J. J., Szumsk, S. A., Growich, J. A., Miller, P. A., Bitler, B. A., Jensen, E. R., Soc., 78, 1508 (1956); 81, 3069 (1959).

\section{Hydroxyproline in Primary Cell Walls of Higher Plants}

VARrous investigators have given evidence for the presence of protein in the cell walls of higher plants ${ }^{1-6}$. We give evidence here for the occurrence of protein in the walls of sycamore (Acer pseudoplatanus L.), and bean (Phaseolus vulgaris). This protein contained hydroxyproline, and differed in this respect from the protein of the cell contents. Hydroxyproline has been found by Steward and Thompson? to occur in the protein of tissue cultures of carrot and potato, and Pollard and Steward ${ }^{8}$ showed that the protein containing this imino-acid was stable in the growing eells and was not metabolized.

The plant tissues used in this work are listed in Table 1. The rotary shaker technique described by Nickell ${ }^{\circ}$ was used for growing the sycamore cell suspensions which were derived from callus tissue originating from explants of secondary cambial tissues taken from the troe in November 1958. Bean cell suspensions were derived from hypocotyl or seed.s. Growth was measured by withdrawing samples from the cultures and determining the dry weight of cells por ml. of suspension over a period of 21 days.

Sycamore and bean cells were broken by shaking a thick suspension in water with glass beads $(2 \mathrm{~mm}$. in diameter) at approximately $50 \mathrm{c} . / \mathrm{sec}$. for $2 \mathrm{~min}$. at $2^{\circ} \mathrm{C}$. in a cell mill ${ }^{10}$. Microscopic oxamination showed

Table 1. ANHYDRo Hydroxyproline CONTENT OF CELLS AND Celi FRACTIONS (PERCENTAGE DRY WEIMHT)

\begin{tabular}{|l|c|c|c|}
\hline & Whole cells & Cell walls & Cell contents \\
\hline Sycamore cell suspensions & $0 \cdot 51$ & 1.28 & $<0 \cdot 1$ \\
Phaseolus vulgaris callus & $0 \cdot 425$ & $2 \cdot 7$ & - \\
Hypocotyl & 0.36 & 0.88 & - \\
\hline
\end{tabular}

